\title{
TIMELINESS COSTS IN WHEAT PRODUCTION SYSTEMS
}

\author{
Ismail, Z.E. ${ }^{1}$; A.E. Abou-Elmagd ${ }^{2}$ and \\ A.E. Abdel-Mageed ${ }^{3}$
}

ABSTRACT

The present study was carried out to design a simulation program based on timeliness of the operations performance for wheat production. Wheat is the most unique of all grain crops in its adaptability to planting in different methods (sowing or drilling, broadcasting and transplanting). The time of harvesting also is changed relative to planting methods consequentially; the quality and the quantity of wheat production may be differ through a harvesting season of bout 30 days. Optimum planting and harvesting operations as well as good timing are needed to minimize the time penalty cost and obtain maximum profits. Timeliness losses due to yield losses are typically expressed as timeliness factors for quantity reduction, in $\mathrm{kg} \mathrm{ha}^{-1}$. The results cleared that the correlation coefficients between the mean yield losses and operation starting of the late sowing period ranged from 0.95 to 0.985 , compared with 0.92 to 0.97 for the early period. The average time penalty loss for the planting operation were about $411.26^{ \pm} 176.60 \mathrm{LE} / \mathrm{fed}$ and $427.35^{ \pm} 234.17 \mathrm{LE} / \mathrm{fed}$ due to a crop being established too early and too late respectively. The best planting date that relating to the highest wheat crop is ranged from 14 to 21 November.

\section{INTRODUCTION}

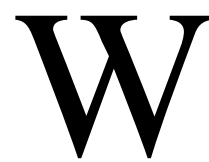

hen a field operation is performed there is normally an optimal time for this operation with respect to the value of the crop. If the operation is performed earlier or later, the value of the crop may decrease due to changes in quantity and/or quality (ASABE, 2006).

1- Prof. of Power technology and farm machinery, Ag. Eng., Dept., Mansoura Un., Egypt. Email: Ismailze221@ mans.edu.eg 2- Prof. of Ag. Eng., Ag. Eng. Dept. Mansoura Univ.

3- Assis. Res. Ag. Eng., Ag. Eng. Res. Inst. (AEnRI) Ag. Res. Center. 
Timeliness costs can be described as a time-related penalty decreasing the total revenue in crop production. This penalty, associated with risk, arises when an operation is performed at a non-optimal time or with nonoptimal capacity of the equipment, affecting the quality or quantity of a crop (Witney, 1995). Timeliness costs arise in all crop production since it is not possible to operate all crops and fields at the optimal time; nevertheless having high machine capacity can reduce the costs. Generally, timeliness costs are higher in areas with short growth season or high precipitation or both (Lund, 1996). Since these costs are partly dependent on planning and scheduling of the field operation and on machine capacity, they are also referred to as indirect machine costs. If timeliness costs are not considered there is a risk of overall costs and machinery capacity requirements being under-estimated. Significant timeliness costs can occur in regions with short periods available for sowing and harvesting, and since they are affected by the weather such costs are specific for regions and are subject to annual variations (De Toro, 2004). Since the size of the timeliness penalty depends on the capacity of the machine used for the field operation. Increased capacity is associated with higher direct machine investments and decreased labour costs (De Toro \& Hansson, 2004a).

Timeliness costs for a specific area or operation are normally calculated using timeliness factors expressing the loss for each day's delay of an operation. Furthermore, timeliness costs are dependent on farm-specific parameters influencing the length of the operation, such as transport distances, labour availability and length of working day. Delays due to weather conditions also affect the length of the operation. When calculating machine capacity, the actual time spent carrying out the operation as well as the time spent on non-productive activities such as turning and adjustment need to be considered (Soerensen, 2003).

Srivastava et al. (2006) mention increasing machine capacity as one way to decrease timeliness costs, as larger machines with greater capacity can accomplish more timely work. In addition, optimal work organization and machinery utilization are important in achieving cost reductions (Soerensen, 2003). Another way to decrease timeliness losses is to plant different crops or varieties with different dates of maturation (Nilsson, 
1987). On the other hand, in some areas excessive moisture content in the soil prevents seeding operations from starting before the optimum time and consequently the fields are sown as they dry (De Toro A. \& Hansson, 2004b). For most harvesting operations, it is not feasible to begin harvesting until the crop is mature (Srivastava et al., 2006). To achieve satisfactory accuracy, particularly in wheat production, it is necessary to calculate timeliness losses in terms of changes in both quantity and quality, since in addition to yield changes, quality parameters such as the nutrient content change with time of harvest and affect the feed value and price of the crop (Witney, 1995). If the machines for harvesting wheat have high capacity, a larger area can be harvested before the rain and consequently the losses can be reduced. Thus, by calculating the value of the wheat at two different harvest times it is possible to determine the timeliness losses at delayed harvest. The result is timeliness factors for wheat harvest, influenced by changes in quantity per feddan that expressed as percentage loss per day $\left(\%\right.$ day $\left.^{-1}\right)$ where a low value of the timeliness factor is advantageous.

The main purpose of this study was to calculate timeliness factors and subsequent timeliness costs for planting wheat crop. The use of the timeliness factors is exemplified by studying timeliness and machine costs for wheat planting in both of Rice mechanization center (RMC) in Kafr El-Sheikh Governorate and Dakahlia governorate. Finally, the factors influencing the timeliness costs such as planting date season, timeliness coefficients and time penalty cost in LE are analyzed.

\section{MATERIAL AND METHODS}

\section{Timeliness Cost Factors}

The timeliness cost factors expressed the combined quality and/or quantity reductions occurring due to delayed operations in economic terms, in LE fed ${ }^{-1} \mathrm{day}^{-1}$. In Egypt, the greater of overall yield loss for wheat crop (Sakha 13), the longer of the time span for establishing the crop and at the smaller capacity of the equipment used. The time penalty cost, TC, due to the untimely establishment of a crop is given by the value of the lost yield (Gunnarsson, 2008): 


$$
\mathrm{T}_{\mathrm{C}}=\mathrm{Y}_{\mathrm{O}} * \mathrm{Y}_{\mathrm{L}} * \mathrm{~A} * \mathrm{P}_{\mathrm{c}}
$$

Where:

$$
\begin{aligned}
& \mathrm{T}_{\mathrm{C}}=\text { time penalty cost } \mathrm{L} . \mathrm{E} \\
& \mathrm{Y}_{\mathrm{o}}=\text { peak yield } \text { ton/fed. } \\
& \mathrm{Y}_{\mathrm{L}}=\text { mean yield losses; } \% \\
& \mathrm{~A}=\text { crop area; fed. } \\
& \mathrm{P}_{\mathrm{c}}=\text { crop price; } \mathrm{LE} / \mathrm{ton}
\end{aligned}
$$

The expected peak crop yield and the optimum date of crop establishment are often known for a particular location. Alternatively, average values which were obtained by further analysis of the experimental dates are presented in table (1) using either the local date or average results, the mean yield losses is computed from the following equation:

$$
Y_{L}=\frac{K_{1}}{3}\left(t_{0}-t_{1}\right)^{2}+\frac{K_{2}}{3}\left(t_{2}-t_{0}\right)^{2}
$$

Where:

$\mathrm{K}_{1}=$ early timeliness coefficient

$\mathrm{K}_{2}=$ late timeliness coefficient

$\mathrm{t}_{0}=$ optimum sowing day number

$\mathrm{t}_{1}=$ operation starting day number

$\mathrm{t}_{2}=$ operation finishing day number

\section{Data Collection Sources}

The study was carried out by collecting huge amounts of data and information needed to supply the data base to constrict the program. Crop data were collected from trial results at various farms in Egypt, over the past twenty years from the following locations; Rice mechanization center (RMC) in Kafr El-Sheikh Governorate.

\section{Planting and Harvesting Dates}

It has been reported in the literature Rev. that the highest yield of wheat was obtained when it was planted during the third week of November This reported experience was one of the motives for the Egyptian Ministry of Agriculture to recommend that the planting date of wheat must be within the period starting from 1 November and ending by 30 November. 
Table (1) Day number, yield, yield losses, $K_{1}$ and $K_{2}$.

\begin{tabular}{|c|c|c|c|c|c|c|c|c|c|c|c|}
\hline Year & D.N & $\begin{array}{c}\text { Yield } \\
\text { (ton/Fed) }\end{array}$ & $\begin{array}{c}\text { Yield } \\
\text { losses } \\
(\%)\end{array}$ & $\mathbf{K}_{1}$ & $\mathbf{K}_{2}$ & Year & D.N & $\begin{array}{c}\text { Yield } \\
\text { (ton/Fed) }\end{array}$ & $\begin{array}{c}\text { Yield } \\
\text { losses } \\
(\%)\end{array}$ & $\mathbf{K}_{1}$ & $\mathbf{K}_{2}$ \\
\hline \multirow[t]{4}{*}{1988} & 321 & 2.52 & 0.00 & & & 1998 & 312 & 2.535 & 9.38 & 0.1955 & \\
\hline & 334 & 2.175 & 13.69 & & 0.2430 & & 324 & 2.7975 & 0.00 & & \\
\hline & 344 & 2.13 & 15.48 & & 0.0878 & & 339 & 2.4 & 14.21 & & 0.1895 \\
\hline & 354 & 2.1 & 16.67 & & 0.0459 & 1999 & 312 & 2.445 & 19.31 & 0.4022 & \\
\hline \multirow[t]{4}{*}{1989} & 293 & 2.1225 & 11.01 & 0.0344 & & & 324 & 3.03 & 0.00 & & \\
\hline & 311 & 2.22 & 6.92 & 0.1228 & & & 344 & 2.37 & 21.78 & & 0.1634 \\
\hline & 324 & 2.385 & 0.00 & & & 2000 & 291 & 2.265 & 22.56 & 0.0661 & \\
\hline & 334 & 2.355 & 1.26 & & 0.0377 & & 309 & 2.43 & 16.92 & 0.2590 & \\
\hline \multirow[t]{3}{*}{1990} & 300 & 2.355 & 6.27 & 0.0389 & & & 323 & 2.925 & 0.00 & & \\
\hline & 322 & 2.5125 & 0.00 & & & 2001 & 324 & 3.0225 & 0.00 & & \\
\hline & 341 & 2.28 & 9.25 & & 0.0769 & & 339 & 2.475 & 18.11 & & 0.2415 \\
\hline \multirow[t]{3}{*}{1991} & 298 & 2.415 & 8.78 & 0.0597 & & & 354 & 2.25 & 25.56 & & 0.0852 \\
\hline & 319 & 2.6475 & 0.00 & & & 2002 & 301 & 2.28 & 24.53 & 0.1520 & \\
\hline & 333 & 2.58 & 2.55 & & 0.0390 & & 323 & 3.021 & 0.00 & & \\
\hline \multirow[t]{3}{*}{1992} & 309 & 2.46 & 4.93 & 0.0875 & & & 342 & 2.4045 & 20.41 & & 0.1696 \\
\hline & 322 & 2.5875 & 0.00 & & & 2003 & 278 & 2.403 & 16.13 & 0.0154 & \\
\hline & 344 & 2.4075 & 6.96 & & 0.0431 & & 319 & 2.835 & 1.05 & 0.0140 & \\
\hline \multirow[t]{3}{*}{1993} & 298 & 2.3025 & 18.78 & 0.0834 & & & 334 & 2.865 & 0.00 & & \\
\hline & 309 & 2.415 & 14.81 & 0.1975 & & 2004 & 306 & 2.505 & 13.47 & 0.1579 & \\
\hline & 324 & 2.835 & 0.00 & & & & 322 & 2.895 & 0.00 & & \\
\hline \multirow[t]{3}{*}{1994} & 293 & 2.268 & 19.14 & \begin{tabular}{|l|l|}
0.0638 \\
\end{tabular} & & & 339 & 2.43 & 16.06 & & 0.1667 \\
\hline & 306 & 2.445 & 12.83 & 0.1332 & & 2005 & 305 & 2.475 & 16.24 & 0.1904 & \\
\hline & 323 & 2.805 & 0.00 & & & & 321 & 2.955 & 0.00 & & \\
\hline \multirow[t]{4}{*}{1995} & 311 & 2.4255 & 17.29 & 0.2305 & & & 339 & 2.445 & 17.26 & & 0.1598 \\
\hline & 326 & 2.9325 & 0.00 & & & 2006 & 309 & 2.55 & 15.84 & 0.2112 & \\
\hline & 343 & 2.2695 & 22.61 & & 0.3461 & & 324 & 3.03 & 0.00 & & \\
\hline & 352 & 2.19 & 25.32 & & 0.1436 & & 339 & 2.5725 & 15.10 & & 0.0004 \\
\hline \multirow[t]{3}{*}{1996} & 311 & 2.58 & 12.07 & 0.2142 & & & 354 & 2.2545 & 25.59 & & 0.0007 \\
\hline & 324 & 2.934 & 0.00 & & & 2007 & 305 & 2.34 & 22.77 & 0.2669 & \\
\hline & 341 & 2.4 & 18.20 & & 0.1889 & & 321 & 3.03 & 0.00 & & \\
\hline \multirow[t]{4}{*}{1997} & 305 & 2.415 & 13.90 & 0.1443 & & & 334 & 2.865 & 5.45 & & 0.0967 \\
\hline & 322 & 2.805 & 0.00 & & & & 349 & 2.295 & 24.26 & & 0.0928 \\
\hline & 344 & 2.34 & 16.58 & & 0.0005 & & & & & & \\
\hline & 354 & 2.175 & 22.46 & & 0.0006 & & & & & & \\
\hline \multirow{2}{*}{\multicolumn{3}{|c|}{ Average (20 years) }} & & & & & & & & & \\
\hline & & & & & & & & 2.518 & & 0.145 & 0.114 \\
\hline \multicolumn{2}{|r|}{ SD } & & & & & & & \pm 0.266 & & \pm 0.096 & \pm 0.092 \\
\hline \multicolumn{2}{|c|}{$\mathrm{CV}, \%$} & & & & & & & 10.576 & & 66.194 & 80.636 \\
\hline
\end{tabular}

This period was taken into consideration when designing the mechanization planning program for wheat production in Egypt.

A mathematical approach was used to determine the Program of prediction of machine timeliness costs. It was concentrated on wheat as a model for the intended crop needed to be mechanized due to its importance as a nutritive crop. Because of its sensitivity to environmental conditions and timeliness. The mathematical model was built on Visual Basic program to predict the timeliness cost of wheat production as 
presented in Visual Basic program. The flow chart of the proposed model was shown in Fig. (1). While the timeliness coefficient is illustrated in the flow chart presented in Fig. (2). The input data for the mathematical model were represented with their units in Fig. (3).

\section{RESULTS AND DISCUSSION}

\section{The Timeliness Coefficients " $K_{1}$ and $K_{2}$ "}

The timeliness coefficients " $\mathrm{K}_{1}$ and $\mathrm{K}_{2}$ " were computed from collected data of 20 years old. That data were drown in Fig. "4". As shown in Fig. (4), it was obvious that increasing the planting season increases the early timeliness coefficients " $\mathrm{K}_{1}$ " until pick point and then comes down. A regression type of polynomial analysis was applied to relate the change in timeliness coefficients " $K_{1}$ and $K_{2}$ " under the effect of planting date " $D_{n}$ ". The obtained regression equations were in the form of:

$$
\begin{array}{ll}
\mathrm{K}_{1}=2.0 * 10^{-8} \mathrm{e}^{0.0511 \mathrm{Dn}} & \mathrm{R}=0.62 \\
\mathrm{~K}_{2}=1.0 * 10^{13} \mathrm{e}^{0.097 \mathrm{Dn}} & \mathrm{R}=0.52
\end{array}
$$

where:

$$
\mathrm{D}_{\mathrm{n}}=\text { planting date }
$$

The timeliness coefficients are listed in table (1) together with standard errors and correlation coefficients. Comparative analytical results for other forms of the yield loss equation achieved high correlation coefficients with the practical result.

\section{The percentage of yield loss}

The percentage of yield loss equations with the relevant timeliness coefficients for early and late establishment, $\mathrm{K}_{1}$ and $\mathrm{K}_{2}$ respectively, over the time period $\left(\mathrm{T}_{2}-\mathrm{T}_{1}\right)$ which spans the optimum organization date gives the mean percentage of yield loss " $Y_{L}$ ". The " $Y_{L}$ " losses are illustrated in Fig. 5 and 6 for the collected data over 12 years from (1997 to 2007). The mathematical equation for the data curve introduces same bias in the data analysis. 


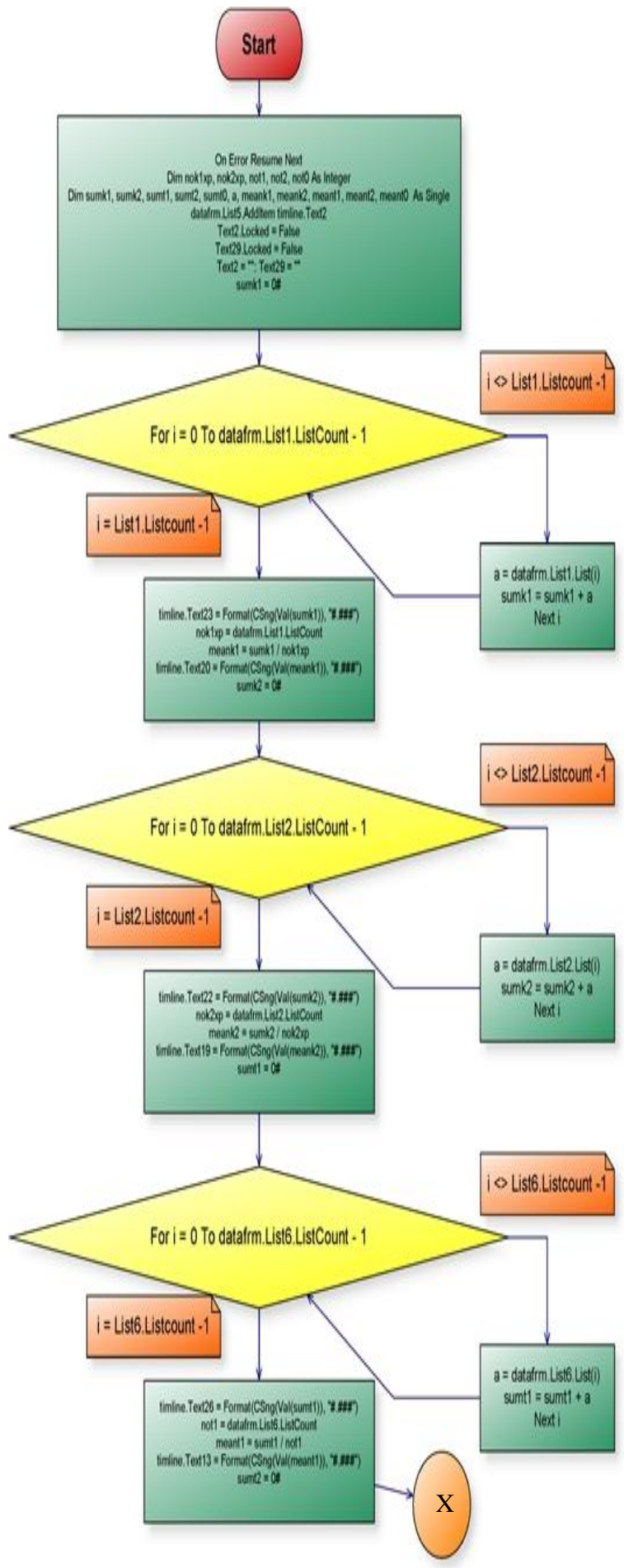

Fig. (1): Flow chart of timeliness-calculation 


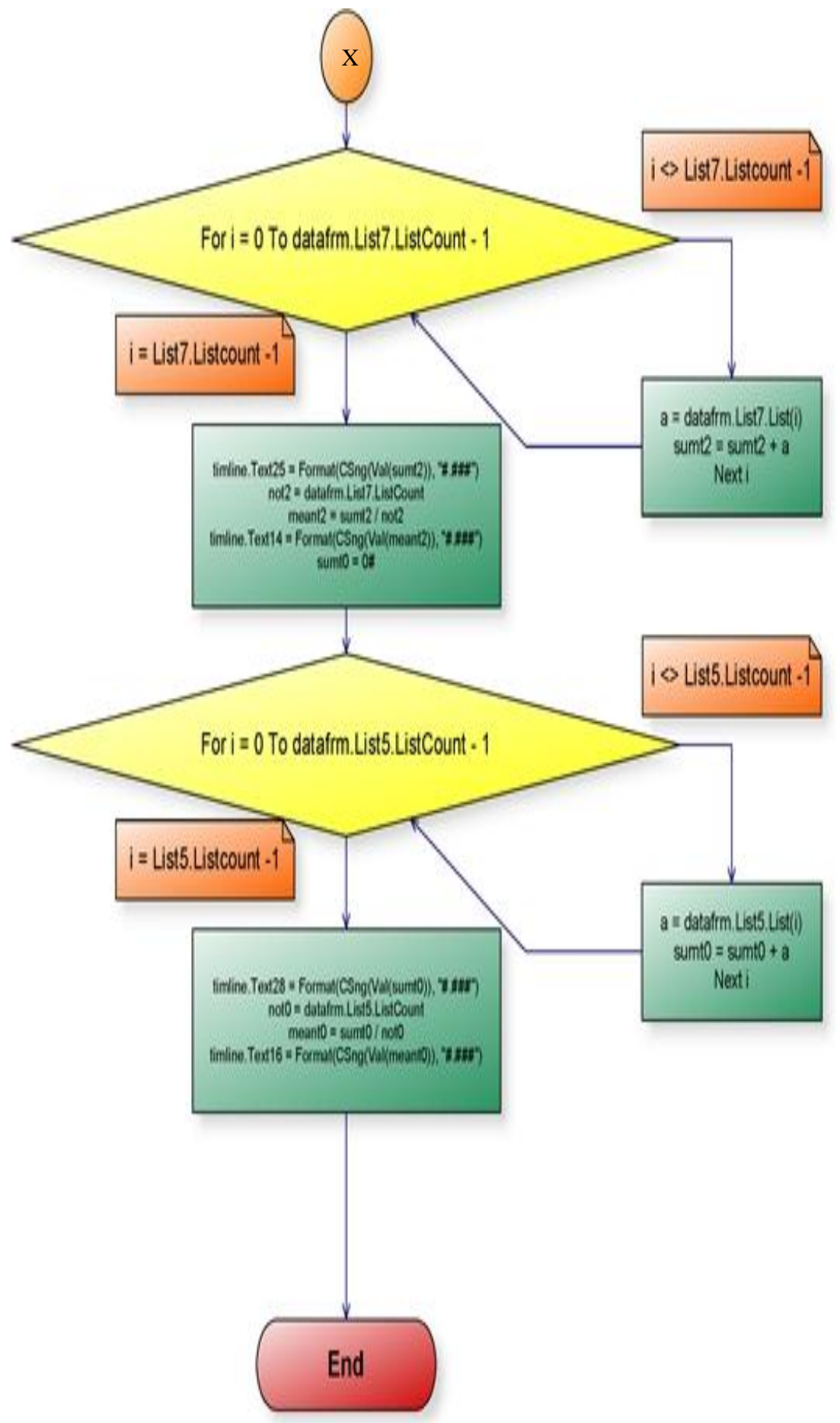

Con. Fig. (1): Flow chart of timeliness-calculation 


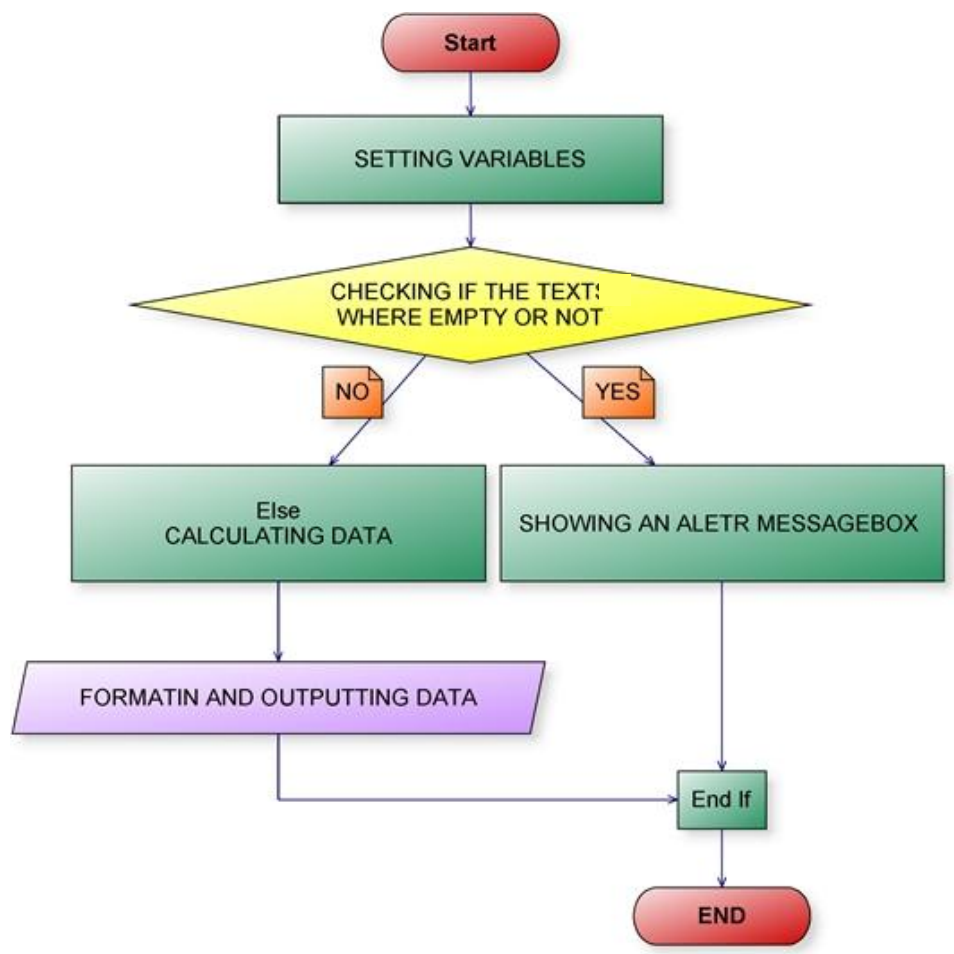

Fig. (2): Flow chart of timeliness coefficient calculate

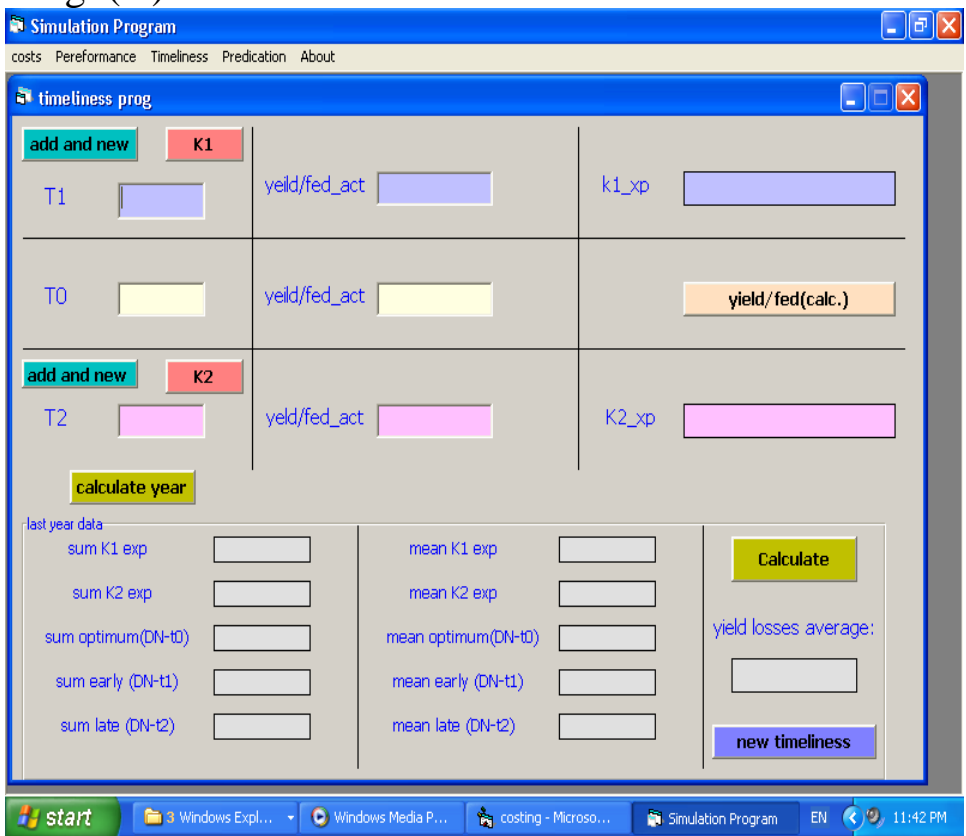

Fig. (3): Input data and their measuring units for timeliness cost of wheat production as presented in Visual Basic program 


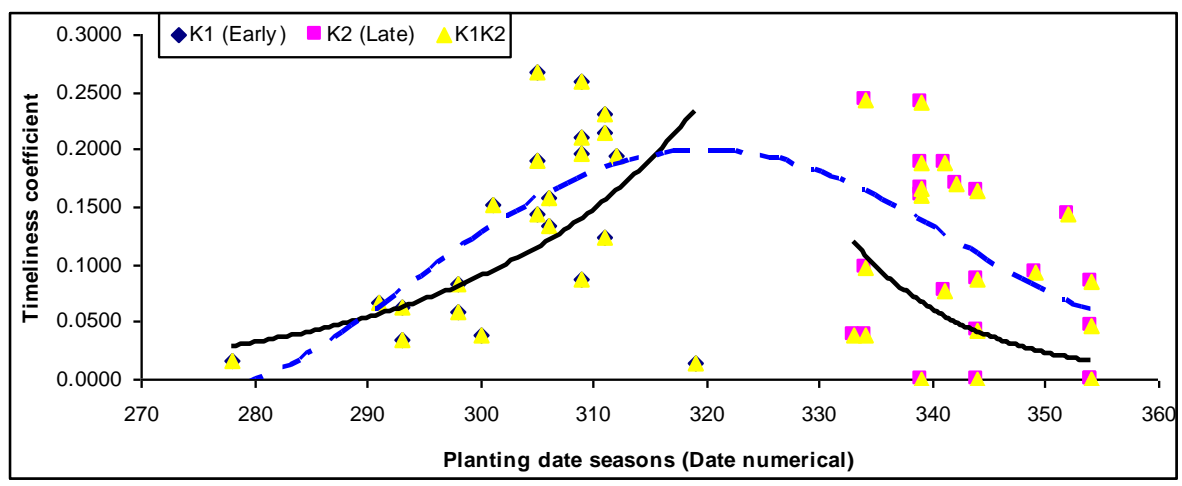

Fig. (4): The timeliness cofficient via planting date

Very high yield losses, of $10 \%$ or more, which occur close to the optimum date of crop establishment, gave a questionable validity, less weighing is accorded to these results by constraining the regression curve to the abscissa at optimum date of crop establishment. Equally, the small numbers of date points giving minimal yield losses of only $1 \%$ or $2 \%$ for very early or very late establishment dates up to 5 weeks from the optimum date are a typical, perhaps because of unusual seasonal conditions, and have only marginal effect on the overall shape of the regression curve. To determine the planting date that recognized the less percentage of " $\mathrm{Y}_{\mathrm{L}}$ " the following steps carried out to determine the optimum planting date:-

$$
\begin{aligned}
\text { "Y } \mathrm{Y}_{\mathrm{m}} & =0.0351\left(\mathrm{D}_{\mathrm{n}}\right)^{2}-22.757\left(\mathrm{D}_{\mathrm{n}}\right)+3690.4 \text { for the data of Fig. } 5 \\
\frac{d^{\prime \prime} \mathrm{Y}_{\mathrm{m}}}{d x} & =2(0.0351)\left(\mathrm{D}_{\mathrm{n}}\right)-22.757 \\
0 & =2(0.0351)\left(\mathrm{D}_{\mathrm{n}}\right)-22.757
\end{aligned}
$$

Then;

$\left(D_{n}\right)=$ the fit planting date $=325=21$ days from the short of November. and

$$
" Y_{m} "=0.0743\left(D_{n}\right)^{2}-47.253\left(D_{n}\right)+7514.5 \quad R^{2}=1.0
$$

for the data of Fig. 6

Then,

$\left(D_{n}\right)=$ the fit planting date $=317.98=14$ from November. 
Consequently, it may be concluded that the optimum planting date that realizing the highest wheat crop is ranged from 14 to 21 November. The correlation coefficients for the late sowing period ranged from 0.95 to 0.985 , compared with 0.92 to 0.97 for the early period. This trend is penalty influenced by the greater volume of data for the early sowing period. Even so, the analysis of early establishment date for sown row crops is particularly variable. It is fortunate, that the accuracy of the analysis is higher for the more critical period in farm scheduling, namely, late sowing.

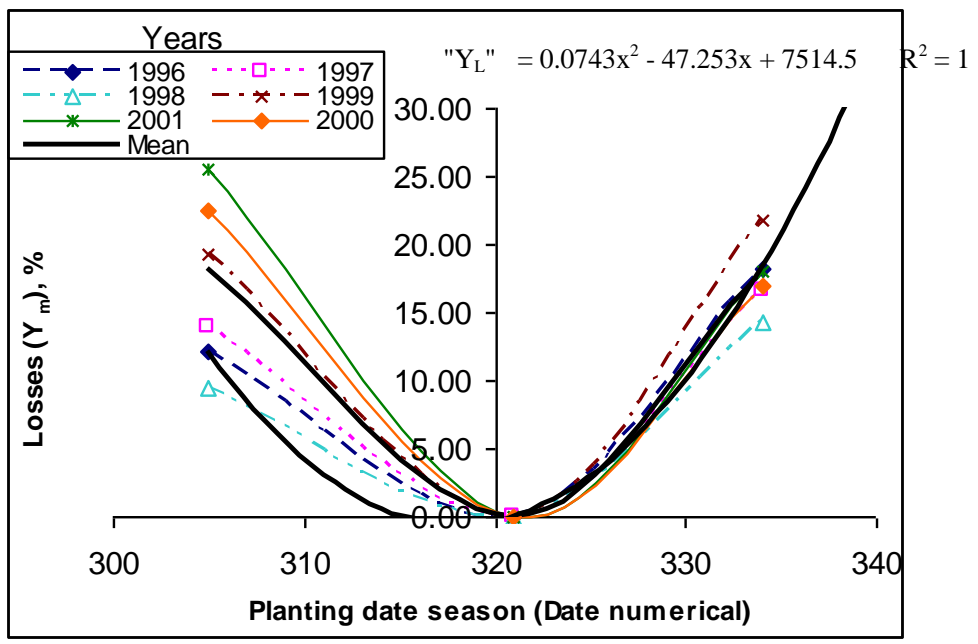

Fig. 5: The relationship between the planting wheat date and " $Y_{L}$ "

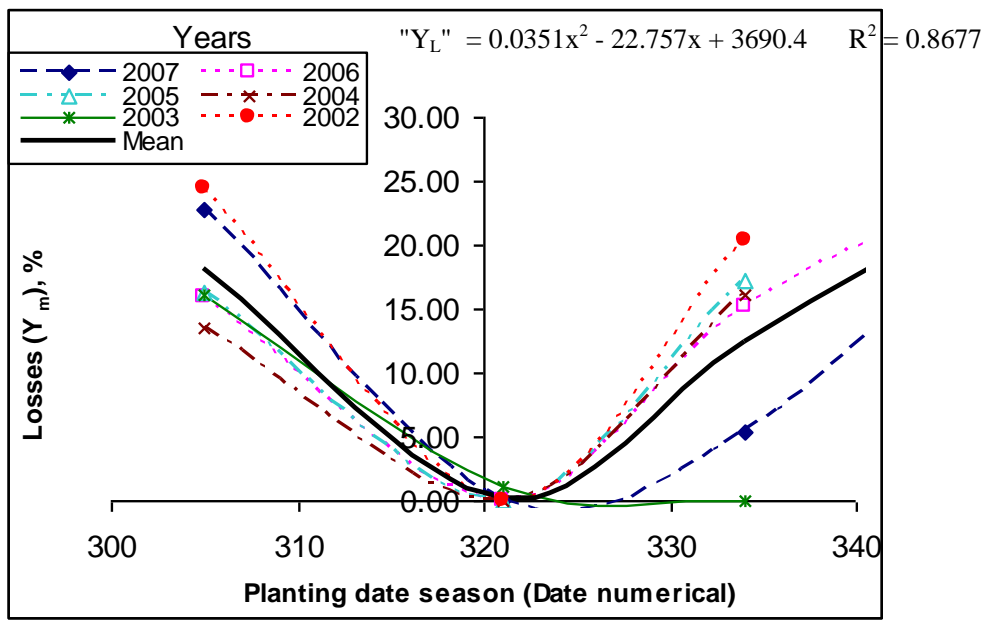

Fig. 6: The relationship between the planting wheat date and " $Y_{L}$ " 
A sowing time span carefully chosen to cover the optimum date of establishment can be skewed off-center by a few days of unfavorable weather, placing much more importance on the yield losses for late sowing than for early sowing. For past 20 years, there was better agreement between the predicted and actual yield losses for the early establishment period than for the late sowing period.

\section{The time penalty cost}

The penalties of untimely operations which constitute a major element in the economics of farm machinery selection can be expressed as the percentage yield loss, due to a crop being established either too early or too late, against a time scale of the number of days deviation from the optimum date of establishment (Table 1). From the crop establishment data and the simulated in Figs. 5 and 6 the penalty of an untimely planting equation was established by adopting equal time spans before and after the optimum planting date.

By calculating the percentage crop yield loss the timeliness cost can be given by equation "1" and by using the program as shown in Fig. 3. For a given duration of time before and after the optimum planting date (day number of crop establishment) the average and main of crop yield losses for both early and late establishments were given in Figs. from 8 to 10 and Table (2). The average time penalty loss for the planting operation were about $411.26^{ \pm} 176.60 \mathrm{LE} /$ fed and $427.35^{ \pm} 234.17 \mathrm{LE} / \mathrm{fed}$ due to a crop

Table (2) The wheat crop penalty cost.

\begin{tabular}{|c|c|c|c|}
\hline \multirow{2}{*}{} & \multicolumn{2}{|c|}{ Penalty Loss LE/Fed } & \multirow{2}{*}{$\begin{array}{c}\text { Penalty Loss } \\
\text { LE/Fed }\end{array}$} \\
\cline { 2 - 3 } & Early & Late & \\
\hline Average & 411.26 & 427.35 & 291.27 \\
\hline SD & \pm 176.60 & \pm 234.17 & \pm 255.26 \\
\hline
\end{tabular}

being established too early and too late respectively. The general in sequence effect for the combination of late and ealy date planting are stablished in Fig. 10. 


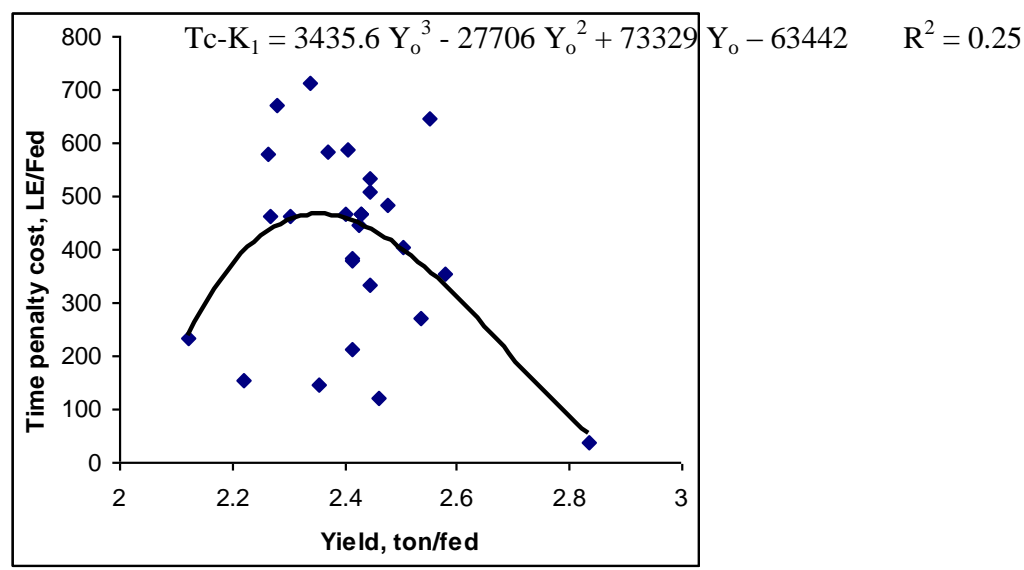

Fig. (8): Time penalty cost loss due to a crop being established too early

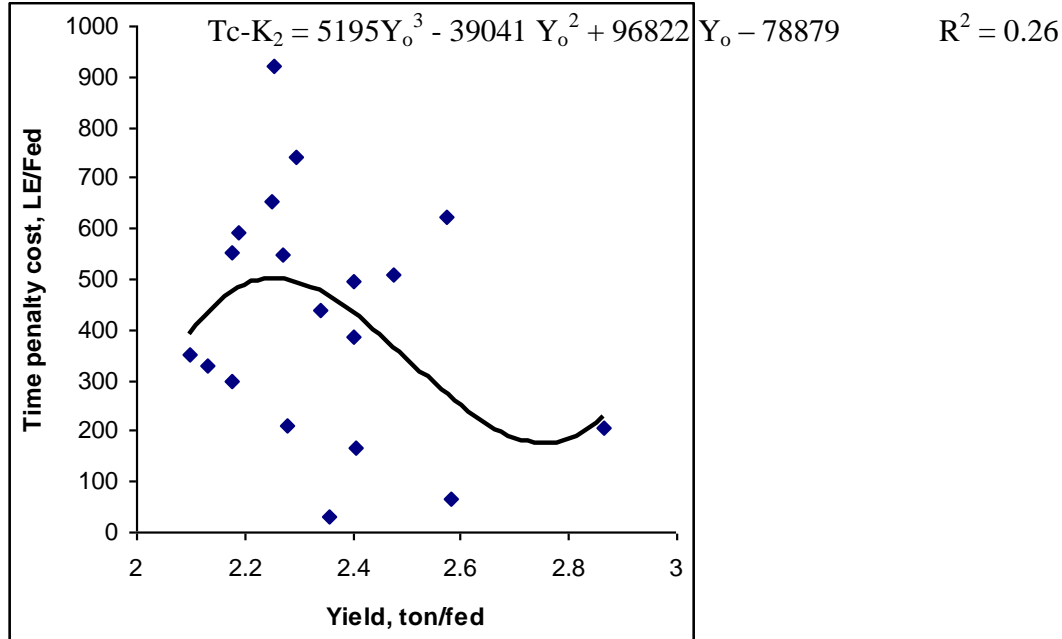

Fig. (9): Time penalty cost loss due to a crop being established too late

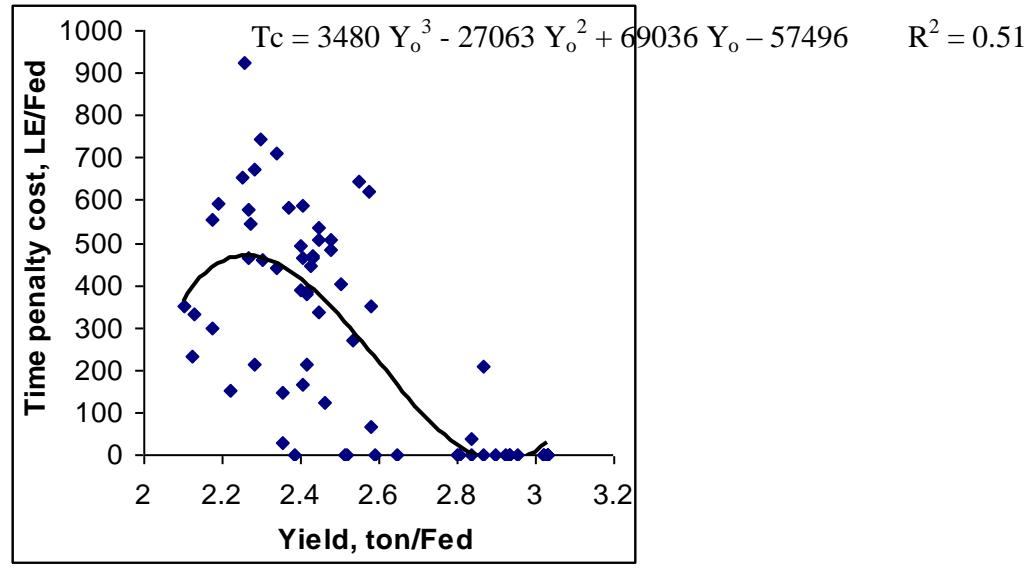

Fig. (10): Time penalty cost loss due to a crop being established too late 
The average time penalty loss for the planting operation were about $291.27^{ \pm}$255.26 LE/fed (one Fed $=0.42$ ha).

\section{CONCLUSIONS}

The research can be concluded that:

1- A simulation program based on timeliness of the operations performance for wheat production was identify.

2- The correlation coefficients between the mean yield losses and operation starting of the late sowing period ranged from 0.95 to 0.985 , compared with 0.92 to 0.97 for the early period. The average time penalty loss for the planting operation were about $411.26^{ \pm}$ 176.60 LE/fed and $427.35^{ \pm} 234.17 \mathrm{LE} /$ fed due to a crop being established too early and too late respectively.

3- The best planting date that relating to the highest wheat crop is ranged from 14 to 21 November

\section{REFERENCES}

ASABE (2006b). Agricultural Machinery Management Data. St. Joseph,

Michigan, USA: American Society of Agricultural and Biological Engineers (ASAE D497.5 FEB2006).

Witney B (1995). Choosing and using farm machines. Land Technology Ltd., Edinburgh, Scotland, UK

Lund M (1996). Mekanisering i ekologiskt lantbruk. En Genomg (ang av problemen och for slag till lo sningar. [Mechanisation in organic farming. A review of problems and suggestions on solutions.] Norsk senter for o" kologisk landbruk, Tingvoll Gard, Norway

De Toro A., A. (2004). Assessment of Field Machinery Performance in

Variable Weather Conditions Using Discrete Event Simulation.

Diss. Swedish University of Agricultural Sciences. Uppsala.

De Toro A; Hansson P-A (2004a). Machinery co-operatives-a case study in Sweden. Biosystems Engineering, 87(1), 13-25.

Gunnarsson, C. (2008). Timeliness Costs in Grain and Forage Production Systems. Doctoral Thesis Swedish University of Agricultural Sciences.

Soerensen, C.G. (2003). Workability and Machinery Sizing for Combine Harvesting. Agricultural Engineering International: the CIGR 
Journal of Scientific Research and Development. Manuscript PM 03 003 Vol V.

Srivastava, A.K., Goering, C.E., Rohrbach, R.P. \& Buckmaster, D.R. (2006). Engineering Principles of Agricultural Machines. 2nd edition. St. Joseph, Michigan, USA: American Society of Agricultural and Biological Engineers.

Nilsson, B. (1987). Planering av arbets- och maskinsystem- resultat och erfarenheter. Uppsala: Department of Agricultural Engineering, Swedish University of Agricultural Sciences. (Institutionsmed de lande 87:03).

De Toro A., A. \& Hansson, P.-A. (2004b). Analysis of field machinery performance based on daily soil workability status using discrete event simulation or on average workday probability. Agricultural Systems 79, 109-129.

Witney, B. (1995). Choosing and Using Farm Machines. Edinburgh, Scotland, UK: Land Technology Ltd.

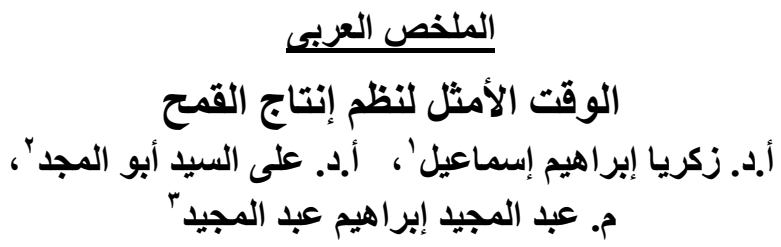

يهدف البحث برنـامج محاكـاه يعتمد على الوقت الغير أمثل (Timeliness) لأداء العمليـات

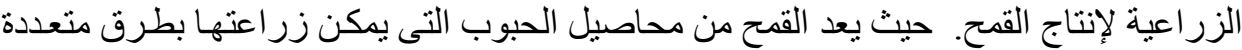

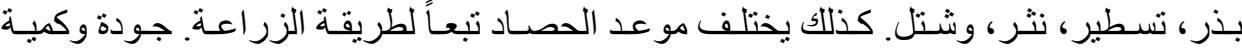

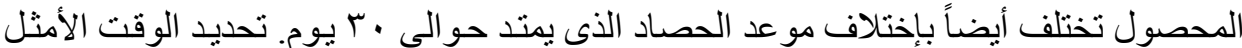

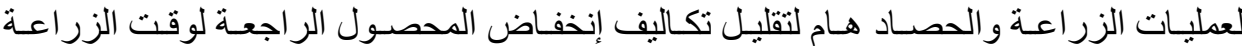
و الحصول على أعلى عائد. برجع الفقد فى المحصول إلى فو اقد الوقت الأمثنل و العو امل المنائثرة

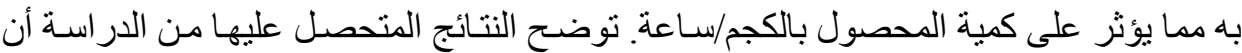

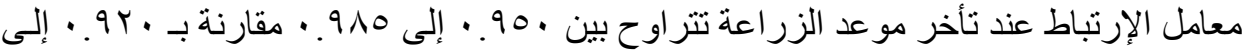
• .

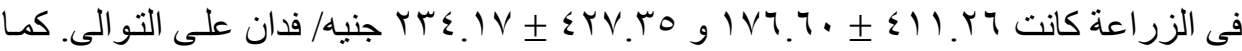
وجد أن أفضل وقت للزر اعة يحقق أعلى محصول يتراوح بين ع ا إلى آ آنوفمبر.

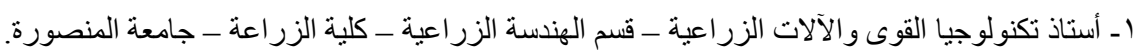

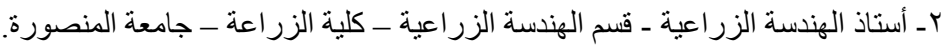

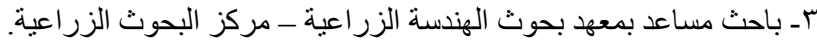

